\title{
PENGEMBANGAN KAPASITAS INSTITUSI DAN SUMBER DAYA MANUSIA DI MADRASAH: PENDEKATAN TOTAL QUALITY MANAGEMENT
}

\author{
Mo'tasim \\ (STIT Al Ibrohimy Galis Bangkalan)
}

\begin{abstract}
Abstrak:
Pengembangan kapasitas institusi dan sumber daya manusia di madrasah merupakan misi penting dalam meningkatkan kualitas pendidikan Islam dewasa ini. Namun, manajerial kelembagaan madrasah masih belum memenuhi ekspektasi yang diharapkan jika dilihat dari kreativitas dan inovasinya. Melihat fenomena tersebut, kiranya upaya untuk menciptakan kondisi yang kondusif dalam mencapai tujuan pendidikan adalah mutlak membutuhkan budaya manajemen yang kualitas melalui Total Quality Management (TQM) adalah salah satu alternatif. Dengan manajemen tersebut, diharapkan efektifitas pola kerja di madrasah akan dapat terwujud secara menyeluruh. Artikel ini mengkaji tentang peran kepala madrasah dalam mengembangkan kapasitas institusi dan sumberdaya manusia melalui pendekatan TQM. Artikel ini mendeskripsikan penerapan TQM dengan library research melalui analisis deskriptif non-statistik sebagai penyajian datanya. Sebagai kesimpulan, kepemimpinan dan manajerial kepala madrasah berperan penting dalam menentukan kebutuhan lembaga dan menyusun visi, misi dan tujuan lembaga. Di sisi lain, efektifitas TQM ditentukan oleh kemampuan kepala madrasah dalam hal manajerial, gagasan pembaharuan, efektifitas proses pembelajaran, pengelolaan tenaga kependidikan yang baik, partisipasi warga madrasah dan masyarakat, akuntabilitas dan motivasi untuk mewujudkan tim kerja yang solid.
\end{abstract}

Kata Kunci: Total Quality Management, Kepala Madrasah, Kapasitas Institusi, Sumber Daya Manusia. 


\begin{abstract}
:
Institutional and human capacity development in madrasah is central in developing islamic education quality nowadays. However, the institutional management in madrasah has not yet meet the expectation from its creativity and innovation. Based upon the phenomenon, this paper offers Total Quality Management (TQM) as an alternative to create conducive atmosphere in madrasah for achieving educational purposes. The management expects holistic-effective workflow in madrasah. This article focuses on the role of madrasah principal in developing institutional and human capacity through the TQM. With library research, this article describes the TQM implementation and provides descriptive non-statistical analysis in providing the data. As a conclusion, the madrasah principal's leadership and managerial role are the very important factors to decide intitutional needs and constructing institutional visions-missions-aims. In addition, the TQM effectiveness depends on the principal's ability in managing, offering innovation, creating effective learning activities, managing staffs, involving stakeholders, promoting accountability, and motivating people for a solid teamwork.
\end{abstract}

\title{
Keywords: Total Quality Management, Madrasah Principal, Institutional Capacity, Human Resource.
}

\section{A. Pendahuluan}

Di Indonesia potret kualitas pendidikan masih memprihatinkan, terutama pendidikan yang bercirikan keislaman seperti madrasah. Salah satu faktor yang membuat kurang berkembangnya madrasah dalam konteks ini adalah manajemen pendidikan yang masih jauh dari harapan. Pemahaman perihal manajemen kurikulum, manajemen keuangan madrasah, manajemen administrasi madrasah, menjadi hal penting untuk diperhatikan. Hal inilah yang menjadi indikator tidak efektif dan sekaligus buruknya kualitas madrasah sebagai lembaga penyelenggara pendidikan. ${ }^{1}$

Efektivitas merupakan suatu dimensi tujuan manajemen yang berfokus pada hasil, sasaran, dan target yang diharapkan. Madrasah yang efektif adalah madrasah yang menetapkan keberhasilan pada input, proses, output dan outcome yang ditandai dengan berkualitasnya komponen-komponen system tersebut. Dengan demikian, efektivitas madrasah bukan sekedar pencapaian sasaran atau

\footnotetext{
${ }^{1}$ Nurhayati Djamas, Madrasah Mandiri (Jakarta :Puslitbang Pendidikan Agama dan Keagamaan,2005), 4.
} 
terpenuhinya berbagai kebutuhan untuk mencapai sasaran, tetapi berkaitan erat dengan syaratnya komponen-komponen sistem dengan mutu, dengan kata lain ditetapkannya pengembangan mutu madrasah. ${ }^{2}$

Mutu sudah menjadi keharusan yang tidak terbantahkan dan merupakan konsep yang paling manjur menjawab berbagai tantangan - tantangan yang semakin kompleks. Mutu menjadi indikator penting efektivitas madrasah. Mutu madrasah harus memperhatikan dan konfirmasi dengan kebutuhan pelanggan quality is conformance to customer requirement.

Berdasarkan hakikat kualitas secara holistik, kualitas pendidikan yang diharapkan tidak saja pada hasil, tetapi juga pada input dan proses, terutama pada proses. Bahkan Allah SWT mewajibkan manusia bekerja keras dan menjamin tujuan sebagai keniscayaan dari proses yang dilakukan secara baik, benar dan bermutu. Manajemen yang handal menjadi juru kunci bagi penciptaan, pemeliharaan dan peningkatan kualitas.

Melihat fenomena di atas, kiranya upaya untuk menciptakan kondisi yang kondusif dalam mencapai tujuan pendidikan adalah mutlak membutuhkan budaya manajemen kualitas. Dengan manajemen tersebut efektivitas madrasah akan dapat terwujud secara sempurna. Akhir-akhir ini dunia pendidikan telah melirik dan mengadopsi konsep-konsep yang menaruh minat secara mendalam terhadap perbaikan input, proses, dan output yang berkualitas, salah satunya adalah konsep Total Quality Management (TQM). ${ }^{3}$ Sebelumnya, TQM hanya dikenal dalam bidang ekonomi (bisnis). Penelitian Musran Munizu memberikan deskripsi bagaimana TQM begitu efektif dalam hal meningkatkan kinerja karyawan di PT Telom Tbk Cabg Makassar. ${ }^{4}$ Hal senada diuangkap oleh Galih Fajar Muttaqin dan Rita Dharmayanti. Dalam tulisannya yang berjudul "Pengaruh Implementasi Total Quality Management terhadap Kinerja Keuangan Dengan Kualitas Kinerja Sebagai Variabel Intervening", mereka memperoleh temuan bahwa TQM berpengaruh

\footnotetext{
${ }^{2}$ Aan Komariah \& Cepi Triatna, Visionary Leadership (Jakarta : Bumi Aksara,2006), 28.

3 Total Quality Mangement (TQM) berasal dari dunia bisnis dan khususnya dalam dunia perusahaan. Oleh karena itu, untuk memahami TQM harus merujuk pada dunia asalnya. Hal ini bukan berarti bahwa metode bisnis lebih unggul dari pada praktek pendidikan, atau bahwa pendidikan akan bisa ditingkatkan hanya dengan mengadopsi bahasa komersial. Lebih dari itu, justru dunia bisnis dapat belajar dari metode yang diterapkan di beberapa lembaga pendidikan. Lihat Eti Rochaety, dkk. Sistem Informasi Manajemen Pendidikan (Jakarta: Bumi Aksara,2006), 96.

${ }^{4}$ Musran Munizu, "Praktik Total Quality Management (TQM) Dan Pengaruhnya Terhadap Kinerja Karyawan (Studi Pada PT. Telkom Tbk. Cabang Makassar)” Jurnal Manajemen dan Kewirausahaan Fakultas Ekonomi Universitas Kriten Petra Surabaya, Vol.12, No. 2, September 2010 .
}

Jurnal Pendidikan Agama Islam

Volume 4 Nomor 2 Nopember 2016

ISSN(p) 2089-1946 \& ISSN(e) 2527-4511

Hal. 208 - 226 
positif pada kinerja kualitas dan keuangan. ${ }^{5}$ Dalam artikel ini penuis berupaya menjadikan TQM sebagai pendekatan dalam dunia pendidikan, terkhusus pendidikan madrasah.

Pendekatan TQM dalam pengembangan pendidikan madrasah merangkum semua pengertian dari konsep tentang kualitas; karenanya disebut sebagai pengelolaan kualitas secara menyeluruh. TQM menekankan pada personal, etika, budaya, dan juga sistem kualitas yang terarah untuk memastikan komitmen dari setiap anggota organisasi dalam usaha perbaikan yang berkesinambungan. Dalam menerapkan TQM di madrasah, maka seorang kepala madrasah dituntut untuk membangun efektivitas maupun efisiensi dalam mendayagunakan sumber-sumber pendidikan. ${ }^{6}$ Di samping itu kepala madrasah harus mampu merumuskan dan mensosialisasikan misi dan visi madrasah pada seluruh staff, mengembangkan filsafat mutu dalam mencapai tujuan yang ditetapkan. Konsep "kualitas" pendidikan harus benar-benar dipahami oleh komponen madrasah yang terlibat langsung atau tidak langsung. Dalam hal ini kepala madrasah sebagai manajer mempunyai peranan yang sangat penting yaitu sebagai penasehat dan sekaligus motor penggerak dalam rangka mencapai peningkatan kulitas madrasah yang diharapkan. Dengan TQM diharapkan akan dapat mengatasi masalah-masalah manajemen yang sering muncul dalam pendidikan Islam.

\section{B. Karakteristik dan Komponen Total Quality Management (TQM)}

Permasalahan dari berbagai lembaga pendidikan baik formal maupun nonformal adalah mengenai mutu atau kualitas hasil pendidikan (output). Dengan memaparkan seluruh kemungkinan kriteria akan hal terbaik dalam memenuhi standarisasi pendidikan, seringkali mereka hanya mampu menunjukkan daftardaftar yang menggambarkan suatu utopia kesempurnaan yang terkesan tidak mungkin tercapai. Mutu memang sudah menjadi keharusan yang tidak terbantahkan. Mutu merupakan indikator penting efektivitas madrasah.

Menurut Crosby, mutu adalah sesuai yang disyaratkan atau distandarkan (conformance to requirement), yaitu sesuai dengan standar mutu yang telah ditentukan, baik inputnya, prosesnya maupun outputnya. Oleh karena itu, mutu

\footnotetext{
${ }^{5}$ Galih Fajar Muttaqin dan Rita Dharmayanti, "Pengaruh Implementasi Total Quality Management terhadap Kinerja Keuangan Dengan Kualitas Kinerja Sebagai Variabel Intervening" Jurnal Akuntansi Fakultas Ekonomi Universitas Tarumanegara, Vol. XIX, No. 01, Januari 2015.

${ }^{6}$ Pada tingkat paling operasional, kepala madrasah adalah orang yang berada di garis terdepan yang mengkoordinasikan upaya meningkatkan pembelajaran yang bermutu. Kepala madrasah diangkat untuk menduduki jabatan yang bertangggung jawab mengkoordinasikan upaya bersama mencapai tujuan pendidikan pada level lembaga masing-masing.
} 
pendidikan yang diselenggarakan madrasah dituntut untuk memiliki baku standar mutu pendidikan. Secara konseptual, mutu adalah kesesuaian dengan kebutuhan pasar. Dalam konsep ini, pendidikan yang bermutu adalah pendidikan yang dapat menghasilkan keluaran, baik pelayanan dan lulusan yang sesuai kebutuhan atau harapan pelanggan (pasar)nya. Sedangkan Fiegenbaum, mengartikan mutu adalah kepuasan pelanggan sepenuhnya (full customer satisfaction). Dalam pengertian ini, maka yang dikatakan madrasah bermutu adalah madrasah yang dapat memuaskan pelanggannya, baik pelanggan internal maupun eksternal. ${ }^{7}$

Sementara menurut Carvin, sebagaimana dikutip oleh Nasution, mutu adalah suatu kondisi dinamis yang berhubungan dengan produk, manusia/tenaga kerja, proses dan tugas, serta lingkungan yang memenuhi atau melebihi harapan pelanggan atau konsumen. Selera atau harapan pelanggan pada suatu produk selalu berubah, sehingga kualitas produk juga harus berubah atau disesuaikan. Dengan perubahan mutu produk tersebut, diperlukan perubahan atau peningkatan keterampilan tenaga kerja, perubahan proses produksi dan tugas, serta perubahan lingkungan organisasi agar produk dapat memenuhi atau melebihi harapan pelanggan. ${ }^{8}$

Namun secara holistik, kualitas pendidikan yang diharapkan tidak saja pada hasil (output), tetapi juga pada input dan proses, terutama pada proses. Bahkan Allah SWT mewajibkan manusia bekerja keras dan menjamin tujuan sebagai keniscayaan dari proses yang dilakukan secara baik, benar dan bermutu. Manajemen yang handal menjadi juru kunci bagi penciptaan, pemeliharaan dan peningkatan kualitas.

TQM merangkum semua pengertian dari konsep tentang kualitas; karenanya disebut sebagai pengelolaan kualitas secara menyeluruh. TQM menekankan pada personal, etika, budaya, dan juga sistem kualitas yang terarah untuk memastikan komitmen dari setiap anggota organisasi dalam usaha perbaikan yang berkesinambungan. ${ }^{9}$ TQM diartikan sebagai manajemen kualitas secara total. Di Indonesia dikenal dengan MMT (Manajemen Mutu Terpadu) yang merupakan suatu pendekatan yang sistematis, praktis, dan strategis bagi penyelenggaraan pendidikan yang mengutamakan kepuasan pelanggan yang bertujuan meningkatkan mutu. Pengertian tersebut tidak menekankan satu komponen dalam sistem pendidikan, tetapi menyangkut seluruh komponen

\footnotetext{
7 Philip B. Crosby, Quality is Free (New York : New American Library, 1979), 58.

8 Nasution, Manajemen Mutu Terpadu (Total Quality Management) (Jakarta : Ghalia Indonesia, 2001), 16.

${ }^{9}$ Agus Fahmi \& Manshur Ghani Sanusi, Konsep Pendidikan Modern (Surabaya : SMA Khadijah, 2006), 67.
} 
penyelenggaraan pendidikan yaitu input, proses, dan output serta semua perangkat yang mendukungnya.

Mulyadi, menjelaskan bahwa TQM adalah suatu sistem manajemen yang berfokus kepada orang yang bertujuan untuk meningkatkan secara berkelanjutan kepuasan customers pada biaya yang sesungguhnya secara berkelanjutan dan terus-menerus. ${ }^{10}$ Sedangkan menurut Mudafir Ilyas, "TQM It's has an objective to improve quality of produc and servies continuously to satisfy the customers". ${ }^{11}$ (TQM adalah sebuah tujuan atau sasaran untuk meningkatkan produk dan pelayanan secara terus-menerus untuk kepuasan pelangggan). Oleh Fandy, disimpulkan bahwa TQM (Total Quality Management) merupakan suatu pendekatan dalam menjalankan usaha yang berusaha memaksimalkan daya saing organisasi melalui perbaikan terus menerus atas produk, jasa, tenaga kerja, proses dan lingkungannya. ${ }^{12}$

Adapun komponen penting TQM, dengan pelanggan sebagai titik utamanya antara lain : pertama, pelanggan. Digambarkan sebagai "suatu rangkaian pelanggan" yang didefinisikan sebagai "individu atau kelompok yang menerima suatu produk atau jasa" sehingga mereka bukan dipertimbangkan sebagai bagian eksternal dari organisasi melainkan hadir pada setiap tahap yang diperlukan untuk melengkapi proses manufaktur suatu produk atau jasa". Hal ini membuat organisasi terobsesi dengan kepuasan dan perhatian pada pelanggan. Kedua, nilainilai: visi mempengaruhi keseluruhan organisasi dengan memberikan gambaran pada tujuan, arah, kesatuan, dan konsistensi. Ketiga, kepemimpinan: memotori visi- hal ini menyangkut sensivitas, kreativitas, pendayagunaan dan suatu komitmen terhadap perubahan melalui perbaikan yang berkesinambungan. Keempat, tim/ kelompok: sarana/ perangkat ideal untuk prosedur operasional yang ditujukan untuk mencapai tujuan dari organisasi melaui kesamaan nilai, tindakan bersama, keterbukaan, dan kepemimpinan situasional. Kelima, proses: menekankan pada pencegahan, dokumentasi prosedur-prosedur (untuk menjamin konsistensi), audit pada kualitas dan umpan balik/ tanggapan yang teratur. Keenam, struktur: memfalisilitasi tim yang mandiri daripada hirarki yang kaku. ${ }^{13}$

Dari komponen tersebut, maka TQM memfokuskan proses atau sistem pencapaian tujuan organisasi. Dengan dimulai dari proses perbaikan mutu, maka TQM diharapkan dapat mengurangi peluang membuat kesalahan dalam menghasilkan produk, karena produk yang baik adalah harapan para pelanggan.

${ }^{10}$ Mulyadi, Total Quality Manajemen (Yogyakarta: UGM, 1998), 10.

${ }^{11}$ Mudafir Ilyas, "Manajemen Mutu Terpadu” Buletin Pengawasan No. 13 dan 14 Tahun, 1998, 15.

12 Fandy Tjiptono dan Anstasia Dian, Total Quality Manajemen (Yogyakarta: Andi, 2001), 4.

${ }^{13}$ Agus Fahmi Konsep Pendidikan Modern, 69-70. 
Jadi, rancangan produk diproses sesuai dengan prosedur dan teknik untuk mencapai harapan pelanggan. Penggunaan metode ilmiah dalam menganalisis data diperlukan sekali untuk menyelesaikan masalah dalam peningkatan mutu. Partisipasi semua pegawai digerakkan agar mereka memiliki motivasi dan kinerja yang tinggi dalam mencapai tujuan kepuasan pelanggan.

\section{Peran dan Kepemimpinan Kepala Madrasah}

Istilah "peran" kerap diucapkan banyak orang. Sering kita mendengar kata peran dikaitkan dengan posisi atau kedudukan seseorang. Atau "peran" dikaitkan dengan "apa yang dimainkan" oleh seorang aktor dalam suatu drama. Mungkin tak banyak orang tahu, bahwa kata "peran", atau role dalam bahasa Inggrisnya, memang diambil dari dramaturgy atau seni teater. Dalam seni teater seorang aktor diberi peran yang harus dimainkan sesuai dengan plot-nya, dengan alur ceritanya, dengan lakonnya.

Lebih jelasnya kata "peran" atau "role" dalam kamus oxford dictionary diartikan : Actor's part; one's task or function. Yang berarti aktor; tugas seseorang atau fungsi. ${ }^{14}$ Istilah peran dalam "Kamus Besar Bahasa Indonesia" mempunyai arti pemain sandiwara (film), tukang lawak pada permainan makyong, perangkat tingkah yang diharapkan dimiliki oleh orang yang berkedudukan di masyarakat. ${ }^{15}$

Ketika istilah peran digunakan dalam lingkungan pekerjaan, maka seseorang yang diberi (atau mendapatkan) sesuatu posisi, juga diharapkan menjalankan perannya sesuai dengan apa yang diharapkan oleh pekerjaan tersebut. Karena itulah ada yang disebut dengan role expectation. Harapan mengenai peran seseorang dalam posisinya, dapat dibedakan atas harapan dari si pemberi tugas dan harapan dari orang yang menerima manfaat dari pekerjaan/posisi tersebut. ${ }^{16}$ Dengan demikian secara sederhana peran kepala Madrasah dapat didefinisikan sebagai seorang tenaga fungsional guru yang diberi tugas untuk memimpin suatu Madrasah dimana diselenggarakan proses belajar mengajar, tempat dimana terjadi interaksi antara guru yang memberi pelajaran dan murid yang menerima pelajaran.

Dari sudut pandang manajemen mutu pendidikan, kepemimpinan pendidikan yang direfleksikan oleh kepala Madrasah mempunyai peran dan kepedulian terhadap usaha-usaha peningkatan mutu pendidikan di satuan pendidikan yang dipimpinnya. Dalam upaya meningkatkan mutu pendidikan diperlukan upaya optimalisasi terhadap semua komponen, pelaksana, dan

\footnotetext{
14 The New Oxford Illustrated Dictionary (Oxford University Press, 1982), 1466.

15 Departemen Pendidikan Nasional, Kamus Besar Bahasa Indonesia (Jakarta : Balai Pustaka, 2005),854.

16 Wahjosumijo, Kepemimpinan Kepala Sekolah (Jakarta : Raja Grafindo Persada, 1999), 83.
} 
kegiatan pendidikan. Salah satu paling penting yang harus dilakukan adalah melalui optimalisasi peran kepala madrasah. Kepala madrasah adalah pemimpin pendidikan yang mempunyai peranan sangat besar dalam mengembangkan mutu pendidikan di madrasah. Berkembangnya semangat kerja, kerjasama yang harmonis, minat terhadap perkembangan pendidikan, suasana kerja yang kondusif dan menyenangkan, perkembangan mutu profesional diantara para guru banyak ditentukan kualitas kepemimpinan kepala madrasah.

Dalam satuan pendidikan, kepala madrasah menduduki dua jabatan penting untuk bisa menjamin kelangsungan proses pendidikan sebagaimana yang telah digariskan oleh perundang-undangan. Pertama, kepala madrasah adalah pengelola pendidikan di madrasah secara keseluruhan. Kedua, kepala madrasah adalah pemimpin formal pendidikan di Madrasahnya.

Sebagai pengelola pendidikan, berarti kepala madrasah bertanggung jawab terhadap keberhasilan penyelenggaraan kegiatan pendidikan dengan cara melaksanakan administrasi madrasah dengan seluruh substansinya. Di samping itu, kepala madrasah bertanggungjawab terhadap kualitas sumber daya manusia yang ada agar mereka mampu menjalankan tugas-tugas pendidikan. Oleh karena itu sebagai pengelola, kepala madrasah memiliki tugas untuk mengembangkan kinerja para personal (terutama para guru) ke arah profesionalisme yang diharapkan.

Sebagai pemimpin formal, kepala madrasah bertanggungjawab atas tercapainya tujuan pendidikan melalui upaya menggerakkan para bawahan ke arah pencapaian tujuan pendidikan yang telah ditetapkan. Dalam hal ini kepala Madrasah bertugas melaksanakan fungsi-fungsi kepemimpinan, baik fungsi yang berhubungan dengan pencapaian tujuan pendidikan maupun penciptaan iklim madrasah yang kondusif bagi terlaksananya proses belajar mengajar secara efektif dan efisien. ${ }^{17}$

Tanggung jawab juga berkaitan dengan resiko yang dihadapi oleh seorang pemimpin, baik berupa sanksi dari atasan atau pihak lain yang berhubungan dengan perbuatan yang dilakukan, maupun yang dilakukan oleh bawahan, guru, karyawan dan tenaga kependidikan. Tanggung jawab seorang pemimpin harus dibuktikan bahwa kapan saja dia harus siap untuk melaksanakan tugas. Dia harus tetap siaga bila ada perintah dari yang lebih atas. Untuk itu, dia harus seorang pekerja keras (hard worker), berdedikasi (dedicated employer), dan seorang saudagar (memiliki seribu akal). ${ }^{18}$

17 Moch. Idhochi Anwar, Administrasi Pendidikan dan Manajemen Biaya Pendidikan (Bandung : Alfabeta, 2003), 75.

18 E. Mulyasa, Pedoman Manajemen Berbasis Madrasah (Jakarta : Departemen Agama RI, Direktorat Jenderal Kelembagaan Agama Islam, 2005), 54 -55. 
Dalam persepektif kebijakan pendidikan nasional, terdapat tujuh peran kepala madrasah yaitu sebagai : (1) edukator (pendidik); (2) manajer; (3) administrator; (4) supervisor; (5) leader (pemimpin); (6) pencipta iklim kerja; (7) wirausahawan; ${ }^{19}$

- Kepala madrasah sebagai pendidik

Kepala madrasah sebagai edukator harus memiliki strategi yang tepat untuk meningkatkan profesionalisme tenaga pendidik, menciptakan iklim Madrasah yang kondusif, memberikan nasehat kepada warga madrasah, memberikan dorongan kepada seluruh tenaga pendidik serta melaksanakan model pembelajaran yang menarik. Kepala madrasah harus berusaha menanamkan, memajukan dan meningkatkan sedikitnya 4 macam nilai, yaitu pembinaan mental, moral, fisik dan artistik. ${ }^{20}$

Pembinaan mental adalah membina para tenaga pendidik tentang sikap batin dan watak. Pembinaan moral adalah pembinaan tentang perbuatan baik dan buruk, sikap dan kewajiban sesuai dengan tugas masing-masing. Pembinaan fisik adalah pembinaan jasmani, kesehatan dan penampilan, sedangkan pembinaan artistik adalah pembinaan tentang kepekaan terhadap seni dan keindahan.

Dalam rangka meningkatkan kinerja sebagai edukator, kepala madrasah harus merencanakan dan melaksanakan program madrasah dengan baik, antara lain : (1) Mengikutkan tenaga pendidik dalam penataran guna menambah wawasan, juga memberi kesempatan kepada tenaga pendidik untuk meningkatkan pengetahuan dan keterampilannya dengan belajar ke jenjang yang lebih tinggi. (2) Menggerakkan tim evaluasi hasil belajar untuk memotivasi peserta didik agar lebih giat belajar dan meningkatkan prestasinya. (3) Menggunakan waktu belajar secara efektif di Madrasah dengan menekankan disiplin yang tinggi.

Menurut M. Athiyah al-Abrasyi, seorang pendidik harus mempunyai sifat: zuhud, mempunyai jiwa yang bersih dari sifat dan akhlak yang buruk, ikhlas dalam melaksanakan tugasnya, pemaaf terhadap peserta didiknya, menempatkan dirinya sebagai seorang bapak/ibu sebelum dia menjadi seorang guru, mengetahui bakat, tabiat dan watak peserta didik dan menguasai bidang studi yang diajarkan. ${ }^{21}$

\footnotetext{
${ }^{19}$ Akhmad Sudrajat, Kompetensi Guru dan Peran Kepala Sekolah (http://www.depdiknas.go.id/ inlink. Diakses pada tanggal 16 September 2016.

20 Sondang P. Siagian, Organisasi, Kepemimpinan dan Perilaku Administrasi (Jakarta: Gunung Agung, 1982), 22.

${ }^{21}$ M. Athiyah al-Abrasyi, At-Tarbiyyah al-Islamiyyah wa Falsafatuha (Mesir: Isa al-Babi alHalabi, 1975), 132.
} 
Kegiatan belajar mengajar merupakan inti dari proses pendidikan dan guru merupakan pelaksana dan pengembang utama kurikulum di Madrasah, kepala Madrasah yang menunjukkan komitmen tinggi dan fokus terhadap pengembangan kurikulum dan kegiatan belajar mengajar di Madrasahnya tentu akan sangat memperhatikan tingkat kompetensi yang dimiliki gurunya, sekaligus juga akan senantiasa berusaha memfalisitasi dan mendorong agar para guru dapat secara terus menerus meningkatkan kompetensinya, sehingga kegiatan belajar mengajar dapat berjalan efektif dan efisien.

- Kepala madrasah sebagai manajer

Tugas manajer adalah merencanakan, mengorganisasikan, mengatur, mengkoordinasikan dan mengendalikan dalam rangka mencapai tujuan yang telah ditetapkan. Manajer adalah orang yang melakukan sesuatu secara benar (people who do things right). ${ }^{22}$ Dengan demikian, kepala Madrasah harus mampu merencanakan dan mengatur serta mengendalikan semua program yang telah disepakati bersama.

Dalam mengelola tenaga pendidikan, salah satu tugas penting yang harus dilakukan kepala Madrasah adalah melaksanakan kegiatan pemeliharaan dan pengembangan profesi para guru. Dalam hal ini kepala Madrasah seyogyanya dapat memfasilitasi dan memberikan kesempatan yang luas kepada guru untuk melaksanakan kegiatan pengembangan profesi melalui berbagai kegiatan pendidikan dan pelatihan, baik yang dilaksanakan madrasah, atau melalui kegiatan pendidikan dan pelatihan diluar madrasah, seperti : kesempatan melanjutkan pendidikan atau mengikuti berbagai kegiatan pelatihan yang diselenggarakan pihak lain.

- Kepala madrasah sebagai administrator

Kepala Madrasah sebagai administrator sangat diperlukan karena kegiatan di Madrasah tidak terlepas dari pengelolaan administrasi yang bersifat pencatatan dan pendokumentasian seluruh program madrasah. Kepala madrasah dituntut memahami dan mengelola kurikulum, administrasi peserta didik, administrasi sarana dan prasarana, dan administrasi kearsipan. Kegiatan tersebut perlu dilakukan secara efektif agar administrasi madrasah dapat tertata dan terlaksana dengan baik.

Kemampuan kepala madrasah sebagai administrator harus diwujudkan dalam penyusunan kelengkapan data administrasi pembelajaran, bimbingan dan konseling, kegiatan praktikum, kegiatan di perpustakaan, data administrasi peserta didik, guru, pegawai TU, penjaga madrasah, teknisi dan pustakawan, kegiatan ekstrakurikuler, data administrasi hubungan Madrasah

22 Vincent Gaspersz, Total Quality Management (Jakarta: Gramedia Pustaka Utama, 2003), 201. 
dengan orang tua murid, data administrasi gedung dan ruang dan surat menyurat.

Kepala madrasah sebagai administrator dalam hal ini juga berkenaan dengan keuangan, bahwa untuk tercapainya peningkatan kompetensi guru tidak lepas dari faktor biaya. Seberapa besar madrasah dapat mengalokasikan anggaran peningkatan kompetensi guru tentunya akan mempengaruhi terhadap tingkat kompetensi para gurunya. ${ }^{23}$ Masalah keuangan adalah masalah yang peka. Oleh karena itu dalam mengelola bidang ini kepala madrasah harus hati-hati, jujur dan terbuka agar tidak timbul kecurigaan baik dari staf maupun dari masyarakat atau orang tua murid.

Banyak keperluan madrasah yang harus dibiayai, dan semakin banyak pula biaya yang diperlukan. Dalam hal ini kepala madrasah harus memiliki daya kreasi yang tinggi untuk mampu menggali dana dari berbagai sumber, diantaranya dapat diperoleh misalnya dari siswa atau orang tua, masyarakat, pemerintah, yayasan, para dermawan dan sebagainya. Disamping itu kepala madrasah juga harus mampu mengalokasikan dana atau anggaran yang memadai bagi upaya peningkatan madrasah.

- Kepala madrasah sebagai supervisor

Sebagai supervisor, kepala madrasah berfungsi untuk membimbing, membantu dan mengarahkan tenaga pendidik untuk menghargai dan melaksanakan prosedur-prosedur pendidikan guna menunjang kemajuan pendidikan. Kepala madrasah juga harus mampu melakukan berbagai pengawasan dan pengendalian untuk meningkatkan kinerja tenaga pendidik. Hal ini dilakukan sebagai tindakan preventif untuk mencegah agar para tenaga pendidik tidak melakukan penyimpangan dan lebih hati-hati dalam melaksanakan tugasnya.

Untuk mengetahui sejauh mana guru mampu melaksanakan pembelajaran, secara berkala kepala madrasah perlu melaksanakan kegiatan supervisi, yang dapat dilakukan meliputi kegiatan kunjungan kelas untuk mengamati proses pembelajaran secara langsung, terutama dalam pemilihan dan penggunaan metode, media yang digunakan dan keterlibatan siswa dalam proses pembelajaran. Dari hasil supervisi ini, dapat diketahui kelemahan sekaligus keunggulan guru dalam melaksanakan pembelajaran, tingkat penguasaan kompetensi guru yang bersangkutan, selanjutnya diupayakan solusi, pembinaan dan tindak lanjut tertentu sehingga guru dapat memperbaiki

${ }^{23}$ Soewaji Lazaruth, Kepala Sekolah Dan Tanggung Jawabnya (Yogyakarta : Penerbit Kanisius, 1993), 26. 
kekurangan yang ada sekaligus mempertahankan keunggulannya dalam melaksanakan pembelajaran. ${ }^{24}$

Menghadapi kurikulum yang berisi perubahan-perubahan yang cukup besar dalam tujuan, isi, metode dan evaluasi pengajarannya, sudah sewajarnya kalau para guru mengharapkan saran dan bimbingan dari kepala madrasah mereka. Dari ungkapan ini, mengandung makna bahwa kepala madrasah harus betul-betul menguasai tentang kurikulum madrasah.

- Kepala Madrasah sebagai leader

Menurut John Gage Allee, "Leader is a guide; a conductor; a commander."25 (pemimpin itu adalah penunjuk pemandu, penuntun dan komandan).Dalam teori kepemimpinan setidaknya kita mengenal dua gaya kepemimpinan yaitu kepemimpinan yang berorientasi pada tugas dan kepemimpinan yang berorientasi pada manusia. Dalam rangka meningkatkan kompetensi guru, seorang kepala Madrasah dapat menerapkan kedua gaya kepemimpinan tersebut secara tepat dan fleksibel, disesuaikan dengan kondisi dan kebutuhan yang ada.

- Kepala Madrasah sebagai pencipta iklim kerja

Budaya dan iklim kerja yang kondusif akan memungkinkan setiap guru lebih termotivasi untuk menunjukkan kinerjanya secara unggul, yang disertai usaha untuk meningkatkan kompetensinya. Oleh karena itu, dalam upaya menciptakan budaya dan iklim kerja yang kondusif, kepala madrasah hendaknya memperhatikan prinsip-prinsip sebagai berikut : (1) para guru akan bekerja lebih giat apabila kegiatan yang dilakukannya menarik dan menyenangkan, (2) tujuan kegiatan perlu disusun dengan dengan jelas dan diinformasikan kepada para guru sehingga mereka mengetahui tujuan dia bekerja, para guru juga dapat dilibatkan dalam penyusunan tujuan tersebut, (3) para guru harus selalu diberitahu tentang dari setiap pekerjaannya, (4) pemberian hadiah lebih baik dari hukuman, namun sewaktu-waktu hukuman juga diperlukan, (5) usahakan untuk memenuhi kebutuhan sosio-psiko-fisik guru, sehingga memperoleh kepuasan.

- Kepala Madrasah sebagai wirausahawan

Dalam menerapkan prinsip-prinsip kewirausaan dihubungkan dengan peningkatan kompetensi guru, maka kepala madrasah seyogyanya dapat menciptakan pembaharuan, keunggulan komparatif, serta memanfaatkan berbagai peluang. Kepala madrasah dengan sikap kewirauhasaan yang kuat

\footnotetext{
${ }^{24}$ Sudarwan Danim, Inovasi Pendidikan : Dalam Upaya Meningkatkan Profesionalisme Tenaga Kependidikan (Bandung: Pustaka Setia, 2002), 59.

25 John Gage Allee, Webster's New Standar Dictionary (New York: Mc Loughlin Brothers Inc., 1969), 214.
} 
akan berani melakukan perubahan-perubahan yang inovatif di lembaganya, termasuk perubahan dalam hal-hal yang berhubungan dengan proses pembelajaran siswa beserta kompetensi gurunya.

Kepala madrasah sebagai wirausahawan harus mampu mencari, menemukan dan melaksanakan berbagai pembaharuan yang innovatif dengan menggunakan strategi yang tepat, sehingga terjalin hubungan yang harmonis antara kepala Madrasah, staf, tenaga pendidik dan peserta didik, di samping itu juga agar pendidikan yang ada menjadi semakin baik. Sejauh mana kepala madrasah dapat mewujudkan peran-peran di atas, secara langsung maupun tidak langsung dapat memberikan kontribusi terhadap peningkatan kompetensi seluruh komponen pendidikan, yang pada gilirannya dapat membawa efek terhadap peningkatan mutu pendidikan di madrasah.

\section{TQM: Kepemimpinan Pendidikan yang Bermutu dan Terpadu di Madrasah}

Kepemimpinan pada dasarnya adalah kemampuan seseorang untuk mempengaruhi orang lain sehingga orang tersebut mau melakukan suatu tindakan untuk mencapai tujuan. Kepemimpinan yang berlangsung pada lembaga pendidikan adalah kepemimpinan pendidikan yang menurut Syafruddin berarti menjalankan proses kepemimpinan yang sifatnya mempengaruhi sumber daya personil pendidikan (guru dan karyawan) agar melakukan tindakan bersama guna mencapai tujuan pendidikan. ${ }^{26}$

Dirawat, menjelaskan kepemimpinan pendidikan sebagai suatu kemampuan dan proses mempengaruhi, mengkoordinir dan menggerakkan orangrang lain yang ada hubungannya dengan pengembangan ilmu pendidikan, pelaksanaan pendidikan dan pengajaran, agar kegiatan-kegiatan yang dijalankan dapat lebih efektif dan efisien di dalam pencapaian tujuan pendidikan dan pengajaran. ${ }^{27}$

Kepemimpinan madrasah bermutu terpadu menuntut adanya pemimpin transformasional, yang menurut Timpe, diartikan sebagai pemimpin yang memiliki kemampuan penciptaan bayangan masa, yaitu memiliki gambaran masa depan madrasah yang ideal dan madrasah yang efektif, yang dapat memuaskan seluruh stakeholders. ${ }^{28}$ Mampu memobilisasi komitmen seluruh warga madrasah untuk mewujudkan madrasah yang ideal dan efektif serta memuaskan pelanggan tersebut menjadi sebuah kenyataan dan mampu melembagakan perubahan,

${ }^{26}$ Syafruddin, Manajemen Lembaga Pendidikan Islam ( Jakarta : Ciputat Press, 2005), 160.

27 Dirawat, dkk., Pengantar Kepemimpinan Pendidikan (Surabaya : Usaha Nasional, 1986), 33.

28 Timpe A. Dale, The Art and Science of Business Management Leadership ( New York : Kend Publishing, Inv, 1987), 342-344.

Jurnal Pendidikan Agama Islam

Volume 4 Nomor 2 Nopember 2016

ISSN(p) 2089-1946 \& ISSN(e) 2527-4511

Hal. 218 - 226 
sehingga madrasah menjadi bermutu sesuai atau melebihi keinginan, kebutuhan dan harapan pelanggannya.

Dalam proses menuju madrasah bermutu terpadu, maka kepala madrasah, komite madrasah, para guru, staf, siswa dan komunitas madrasah harus memiliki obsesi dan komitmen terhadap mutu, yaitu pendidikan yang bermutu. Memiliki visi dan misi mutu yang difokuskan pada pemenuhan kebutuhan dan harapan para pelanggannya, baik pelanggan internal, seperti guru dan staf, maupun pelanggan eksternal seperti siswa, orang tua siswa, masyarakat, pemerintah, pendidikan lanjut dan dunia usaha.

Dalam implementasi Total Quality Management (TQM), kepala madrasah merupakan motor penggerak, penentu arah kebijakan madrasah/ madrasah, yang akan menentukan bagaimana tujuan-tujuan madrasah dan pendidikan pada umumnya direalisasikan. Sehubungan dengan TQM, kepala madrasah dituntut untuk senantiasa meningkatkan efektifitas kinerja, sehingga TQM sebagai paradigma baru manajemen pendidikan dapat memberikan hasil yang memuaskan.

Pendidikan yang berfokus pada mutu menurut konsep Juran adalah bahwa dasar misi mutu sebuah madrasah mengembangkan program dan layanan yang memenuhi kebutuhan pengguna seperti siswa dan masyarakat. Masyarakat dimaksud adalah secara luas sebagai pengguna lulusan, yaitu dunia usaha, lembaga pendidikan, pemerintah dan masyarakat luas, termasuk menciptakan usaha sendiri oleh lulusan. ${ }^{29}$ Di samping itu, dalam menerapkan manajemen mutu terpadu harus mengadakan perbaikan berkelanjutan, baik produk lulusannya, penyelenggaraan atau layanannya, sumber daya manusia (SDM) yang memberikan layanan, yaitu kepala madrasah, para guru dan staf, proses layanan pembelajarannya dan lingkungannya.

Efektivitas atau kunci keberhasilan maupun kegagalan implementasi TQM adalah management commitment. Apabila manajemen mempunyai dan memegang teguh komitmennya, kemungkinan besar mereka akan berhasil. Sebaliknya, apabila mereka kurang komitmen bisa di pastikan bahwa lembaga akan mengalami kegagalan mencapai TQM. ${ }^{30}$ Komitmen ini setidaknya, menurut Dobbind (1995) meliputi 3 hal, yaitu waktu, antusiastitas (enthusiasm) dan tersedianya sumbersumber (resource) dalam organisasi. Di samping itu harus diikuti dengan employee involment (keterlibatan menyeluruh) sehingga setiap individu dalam suatu lembaga/organisasi adalah ikut menentukan tingkat kualitas yang di capai.

29 J. M. Juran, Leadership for Quality (USA : Juran Institute, Inc., 1989), 23-24.

30 Nanang Fatah, Konsep Manajemen MBS dan Dewan Sekolah (Bandung: Pustaka Bani Quraisy, 2006), 125. 


\section{E. Manajemen Pengendalian Mutu Madrasah: Kapasitas Institusi dan SDM}

Menandai suatu insitusi yang bermutu diperlukan pembuktian melalui produk yang dihasilkannya. Pembuktian terhadap pendidikan bukanlah hal yang mudah karena sifatnya yang intangible maka perlu adanya jaminan terhadap kualitas pendidikan. Tolok ukur bagi jaminan kualitas (quality assurance) pendidikan lebih diapresiasi sebagai efektifitas madrasah. Dengan demikian, berbicara efektifitas madrasah tidak dapat dipisahkan dengan mutu madrasah.

Mutu madrasah adalah mutu semua komponen yang ada dalam sistem pendidikan, artinya efektifitas madrasah tidak hanya dinilai dari hasil semata, tetapi sinergitas berbagai komponen dalam mencapai tujuan yang telah ditetapkan dengan bermutu. Sebagaimana dikatakan sallis sebagai berikut : (1) Rencana strategis memberikan visi jangka panjang yang diwujudkan dalam program yang bersifat operasional dalam menentukan pasar dan corak budaya yang diinginkan. (2) Kebijakan mutu yang memberikan pola standar program utama yang berisi pernyataan tentang hak-hak peserta didik. (3) Organisasi mutu sebagai wadah kegiatan dalam mengatur, mengarahkan dan memonitor pelaksanaan program. (4) Metode penyampaian kurikulum ditetapkan dengan rinci untuk setiap aspek program. (5) Bimbingan dan penyuluhan bagi peserta didik yang terintegrasi dengan pelaksanaan kurikulum. (6) Manajemen belajar di organisasi sesuai dengan spesifikasi materi kurikulum. (7) Desain kurikulum termasuk dokumentasi tujuan dan sasaran dari setiap spesifikasi program harus didasarkan pada kebutuhan peserta didik dan masyrakat pemakai. (8) Pengangkatan, pelatihan, dan pengembangan tenaga kependidikan yang sesuai dan terarah pada kompetensi profesional dan karier staff selanjutnya. (9) Monitoring dan evaluasi yang kontinu melalui mekanisme dan metode yang sesuai dengan proses terhadap kemajuan prestasi individu dan keberhasilan program. (10) Pengaturan administratif yang mendokumentasikan segala bentuk dokumen mengenai peserta didik termasuk sistem finansialnya yang valid. (11) Sistem review lembaga yang dapat membangun kepercayaan dan sekaligus mengevaluasi performa lembaga secara keseluruhan serta umpan balik bagi perencanaan strategi selanjutnya. ${ }^{31}$

Ditinjau dari manajemen organisasinya, karakteristik madrasah efektif dapat ditinjau dari tiga aspek, yaitu di antaranya: Pertama, Manajemen kelembagaan. Aspek manajemen kelembagaan ini menekankan pada pemberdayaan madrasah sebagai pusat pembelajaran, pendidikan dan pembudayaan madrasah. Manajemen kelembagaan madrasah adalah tinjauan madrasah efektif dari sudut penataan yang dilakukan kepala madrasah terhadap

${ }^{31}$ Edward Sallis, Total Quality Management in Education (Jogjakarta : IRCiSoD, 2007), 258. 
bidang-bidang garapan madrasah, yaitu kesiswaan, ketenagaan, kurikulum, sarana dan prasarana, keuangan dan kemitraan madrasah dengan masyarakat.

- Kesiswaan

Siswa akan belajar dengan efektif bila kurikulum dikembangkan secara gradual (bertahap) berdasarkan kebutuhan dan kepentingan siswa. Siswa yang memiliki masalah dalam perilakunya merasa tersisihkan jika kurikulum yang diajarkan kepada mereka tidak didesain sesuai dengan kebutuhan mereka, dan, terlebih lagi jika peraturan-peraturan madrasah (madrasah) tidak disusun secara fair dan efektif dengan melibatkan mereka. ${ }^{32}$

Madrasah efektif ditinjau dari manajemen kesiswaan adalah diperolehnya siswa yang siap belajar dan dibuat beberapa rencana strategis dan operasional tentang kesiswaan untuk pembelajarannya, serta untuk pengembangan aspek keagamaan, kesehatan, kesenian dan hubungan sosialnya.

Manajemen kesiswaan dimulai saat siswa masuk madrasah dengan melalui seleksi yang adil dan jujur, rekrutmen dan pembinaan terhadap siswa, serta melaksanakan layanan bimbingan dan konseling bagi pemecahan masalah (problem solving) peserta didik.

Manajemen madrasah yang efektif bagi bidang kesiswaan diarahkan untuk menumbuhkembangkan kecerdasan, minat dan bakat, meningkatkan keimanan dan ketakwaan, dan untuk menegakkan disiplin siswa. Indikator bahwa siswa telah di manaj dengan baik adalah diperolehnya siswa yang memiliki grade yang cukup bahkan lebih dari cukup, siswa aktif mengikuti kegiatan di madrasah, prestasi akademik maupun ekstrakurikulernya baik, tidak bolos, tidak tinggal kelas, dan tidak drop out.

- Manajemen ketenagaan

Manajemen ketenagaan adalah upaya menata para personel madrasah dalam keahlian dan hubungan sosialnya, mulai dari personel diterima bekerja sampai kepada pengembangan kariernya. Kepala madrasah tidak hanya memusatkan diri untuk pembinaan dan pengembangan keahlian personel, tetapi kepuasan kerja personel menjadi pertimbangan pokok dalam menetapkan kebijakan madrasah tentang pembinaan personel. Manajemen keahlian guru diarahkan pada kemampuan profesional guru untuk menyelenggarakan pembelajaran, sedangkan manajemen sosialnya lebih diarahkan pada bagaimana guru memiliki kematangan sosial maupun emosional dalam berinteraksi dengan siswa dan personel.

32 Departemen Agama RI Direktorat Jenderal Kelembagaan Agama Islam, Desain Pengembangan Madrasah (Jakarta : DEPAG RI, 2004), 28-29. 
- Manajemen kurikulum

Adanya pengorganisasian kurikulum yang dapat berupa analisis kurikulum yang dijabarkan ke dalam komponen-komponen GBPP dan silabus. Dengan banyaknya inovasi dalam kurikulum, kepala madrasah dituntut untuk lebih responsif dan adaptif terhadap perubahan melalui melalui reorientasi dan restrukturisasi kurikulum terutama dalam silabus dan implementasinya. ${ }^{33}$ Mempersiapkan peserta didik yang memiliki berbagai kompetensi pada hakikatnya merupakan upaya untuk menyiapkan peserta didik yang memiliki kemampuan intelektual, emosional, spiritual, dan sosial yang bermutu tinggi, antara lain berupa ketrampilan motorik/manual, kemampuan intelektual, sosial dan emosional.

Kepala madrasah ditantang untuk mewujudkan inovasi kurikulum melalui peningkatan relevansi kurikulum dengan program life skills sebagai salah satu fokus analisis dalam pengembangan kurikulum. Dalam implementasinya pengembangan life skills meliputi ketrampilan hidup yang relevan yang dipelajari madrasah setelah menyelesaikan satuan program belajar tertentu, bahan belajar yang harus dipelajari agar ketrampilan hidup tersebut dikuasai siswa agar benar-benar dikuasai siswa yang mempelajarinya, sarana dan prasarana pendukung kepemilikan ketrampilan yang diinginkan, dan indikator keberhasilan peserta didik yang menngikutinya.

- Manajemen sarana prasarana

Manajemen sarana dan prasarana adalah manajemen sarana madrasah dan sarana bagi pembelajaran. Manajemen sarana oleh kepala madrasah meliputi ketersediaan dan pemanfaatan sumber belajar bagi guru, ketersediaan sumber belajar bagi siswa, pemanfaatan sumber belajar oleh siswa, serta penataan ruangan-ruangan yang dimiliki. Madrasah yang saranaprasarananya di-manaj dengan baik akan berbeda dengan madrasah yang sarana-prasarananya kurang di-manaj dengan baik. Sarana yang di- manaj akan menampilkan kenyamanan, keindahan, kemutakhiran, dan kemudahan dalam penggunaannya.

- Manajemen keuangan

Penataan keuangan madrasah harus didasarkan pada keadilan dan tranparansi. Keuangan madrasah meliputi penggalian sumber-sumber dana pendidikan, pemanfaatan dana, dan pertanggungjawabannya. ${ }^{34}$ Dalam

${ }^{33}$ Hendyat Soetopo \& Wasty Soemanto, Pembinaan dan Pengembangan Kurikulum Sebagai Subtansi Problem Administrasi Pendidikan (Jakarta : Bumi Aksara, 1993), 45.

${ }^{34}$ Sebelum tahun anggaran berjalan, Kepala madrasah harus sudah menyusun Rencana Anggaran Pendapatan Dan Belanja Madrasah (RAPBS) dalam jangka waktu satu tahun ke depan. Rencana anggaran pendidikan tersebut berisi seluruh rencana pendapatan dan 
mengelola dana yang diperoleh dari berbagai sumber maka pihak madrasah harus benar-benar bisa mengelola keuangan secara rinci cermat, dan teliti. Dalam hal ini dikarenakan banyaknya kebutuhan yang harus dipenuhi dalam mengembangkan madrasah.

- Manajemen kemitraan madrasah dengan masyarakat

Masyarakat merupakan mitra untuk mengembangkan madrasah. Madrasah tidak dapat maju pesat tanpa bantuan masyarakat. Oleh karena itu, kemitraan dengan masyarakat harus terus terjalin. Manajemen kemitraan madrasah dengan masyarkat mengakomodasi kepantingan-kepentingan madrasah kepada masyarakat dan sebaliknya. Realisasinya dapat berupa terwujudnya program kemitraan dalam dewan madrasah/komite madrasah dan adanya partisipasi masyarakat dalam pengelolaan madrasah.

Kedua, layanan pembelajaran. Layanan pembelajaran merupakan aspek utama organisasi madrasah. Madrasah yang efektif senantiasa responsif dan adaptif terhadap perkembangan lingkungan yang kompleks dan dan penuh ketidakpastian. Layanan pembelajaran merupakan urusan utama madrasah yang menjadi patokan, terjadi atau tidaknya perubahan kemampuan siswa sebagai representasi dari upaya-upaya yang dilakukan guru dan manajemen madrasah. Oleh karena itu, layanan pembelajaran madrasah efektif ditujukan pada penciptaan madrasah sebagai organisasi pembelajar (learning organization). Organisasi pembelajar (learning organization) adalah organisasi yang memberikan fasilitas belajar bagi anggota-anggotanya dan melakukan perubahanperubahan secara terus menerus sebagai respon terhadap kebutuhan, harapan dan aspirasi dari orang-orang, baik yang ada di dalam maupun di luar organisasi yang selalu berubah.

Organisasi pembelajar (learning organization) adalah organisasi yang efektif karena misinya selaras dengan misi madrasah efektif, yaitu terjadinya belajar secara kontinu dan selalu mengedepankan keterlibatan seluruh personel untuk belajar dalam berbagai tingkat. 35

Ketiga, kompetensi siswa. Kompetensi siswa adalah kemampuan siswa yang dihasilkan selama dia mengikuti pembelajaran, artinya seberapa jauh siswa menyerap materi yang disampaikan guru, seberapa persen tujuan yang telah ditetapkan guru dapat dikuasai siswa, dan seberapa baik siswa mengikuti aturanaturan yang telah ditetapkan, berinteraksi dengan dengan lingkungan sosialnya, dan kinerja yang ditunjukkannya dalam memecahkan masalah-masalah belajar

pengeluaran anggaran madrasah dan disusun oleh kepala madrasah bekerjasama dengan para guru, staff dan komite madrasah.

Komariah, Visionary Leadership, 65.35 
dari kehidupan. ${ }^{36}$ Kompetensi pengetahuan dan ketrampilan adalah kompetensi yang mudah dinilai, diberikan, dilatihkan, diajarkan, dialami, dan dikembangkan karena merupakan kompetensi yang berada di permukaan yang cenderung dapat di lihat. Sedangkan kompetensi konsep diri, watak, dan motif bersifat lebih tersembunyi, lebih dalam, dan berperan sebagai sumber dari kepribadian yang tidak mudah untuk dinilai dan dikembangkan.

Kompetensi harus dimiliki oleh siswa SMU/MA yaitu selain dapat digunakan untuk menembus seleksi masuk perguruan tinggi favorit, yang terkesan sebagai kompetensi akademik, juga untuk melanjutkan kehidupannya di masyarakat, artinya selain kompetensi untuk dapat bergaul dan hidup bersama di tengahtengah masyarakat, siswa juga harus memiliki kemampuan menghasilkan materi dari sejumlah keahliannya. Usia individu tingkat SMU adalah usia yang cukup dewasa dan tidak sedikit dari mereka yang melanjutkan kehidupan ke kehidupan yang sebenarnya. Oleh karena itu, mereka harus dibekali dengan kemampuan life skills (kecakapan hidup). Kecakapan hidup lebih luas dari ketrampilan untuk bekerja, apalagi sekedar ketrampilan manual. Artinya, kecakapan hidup ini mencakup kemampuan individu untuk menyelesaikan berbagai persoalan kehidupannya yang bersifat praktik sosial maupun individual.

\section{F. Kesimpulan}

Sebagai bagian akhir dari artikel ini, penulis memberi kesimpulan behwa kepala madrasah adalah pemimpin pendidikan yang mempunyai peranan sangat besar dalam mengembangkan mutu pendidikan di madrasah. Kepala madrasah bertanggung jawab terhadap keberhasilan penyelenggaraan kegiatan pendidikan serta bertanggungjawab atas pengembangan kapasitas institusi dan SDM di madrasah melalui upaya menggerakkan para bawahan ke arah pencapaian tujuan pendidikan yang telah ditetapkan. Ada beberapa karakteristik yang tercakup dalam pendekatan TQM, di antaranya yaitu: fokus pada pelanggan, obsesi tinggi terhadap kualitas (budaya kualitas), inovasi terus menerus, penggunaan pendekatan ilmiah dalam pengambilan keputusan dan pemecahan masalah, komitmen jangka panjang kerja sama tim (team work).

Sementara, komponen penting dalam meningkatkan kapasitas intitusi dan SMD dengan pendekatan TQM adalah : pelanggan, nilai-nilai, kepemimpinan, tim/ kelompok, proses, dan struktur. Kepala madrasah adalah elemen kunci keberhasilan implementasi TQM. Pasalnya, efektifitas peran kepala madrasah merupakan hal yang sangat penting dalam meningkatkan kapasitas institusi dan SDM di madrasah. Kepala madrasah sebagai pengelola pendidikan bertanggung jawab terhadap keberhasilan penyelenggaraan kegiatan pendidikan. Di samping

\footnotetext{
${ }^{36}$ Departemen Pendidikan Nasional, Direktorat Jenderal Pendidikan Dasar dan Menengah, Interaksi Belajar Mengajar (Jakarta : 2004), 10-11.
} 
itu, kepala madrasah juga bertanggungjawab terhadap kualitas sumber daya manusia yang ada agar mereka mampu menjalankan tugas-tugas pendidikan. Oleh karena itu, sebagai pengelola, kepala madrasah mempunyai komitmen terhadap pengembangan kinerja para personal (terutama para guru) ke arah profesionalisme yang diharapkan. Sistem monitoring yang ketat dan fleksibel serta evaluasi yang cermat harus selalu dikedepankan oleh seluruh komponen lembaga madrasah. Hal ini penting sebagai upaya peningkatan mutu madrasah secara keseluruhan.

\section{G. Referensi}

Abrasyi (al), M. Athiyah. At-Tarbiyyah al-Islamiyyah wa Falsafatuha. Mesir: Isa alBabi al-Halabi, 1975.

Anwar Moch. Idhochi. Administrasi Pendidikan dan Manajemen Biaya Pendidikan. Bandung : Alfabeta, 2003.

Crosby, Philip B. Quality is Free. New York : New American Library, 1979.

Dahlan M. Y. Al-Barry, L. Lya Sofyan Yacub. Kamus Induk Istilah Ilmiah. Surabaya : Target Press Surabaya, 2003.

Departemen Agama RI. Direktorat Jenderal Kelembagaan Agama Islam. Desain

Pengembangan Madrasah. Jakarta : Direktorat Jenderal Kelembagaan Agama Islam, 2004.

Departemen Pendidikan Nasional. Kamus Besar Bahasa Indonesia. Jakarta : Balai Pustaka, 2005.

Departemen Pendidikan Nasional. Direktorat Jenderal Pendidikan Dasar dan Menengah. Interaksi Belajar Mengajar. Jakarta : Direktorat Jenderal Pendidikan Dasar dan Menengah, 2004.

Dirawat. Pengantar Kepemimpinan Pendidikan. Surabaya : Usaha Nasional, 1986. Fahmi, Agus \& Manshur Ghani Sanusi. Konsep Pendidikan Modern. Surabaya : SMA Khadijah, 2006.

Fatah, Nanang. Konsep Manajemen MBS dan Dewan Madrasah. Bandung: Pustaka Bani Quraisy, 2006.

Gage. Allee John. Webster's New Standar Dictionary. New York: Mc Loughlin Brothers Inc, 1969.

Gaspersz, Vincent. Total Quality Management. Jakarta: Gramedia Pustaka

Utama, 2003.

Juran, J. M. Leadership for Quality. USA : Juran Institute, Inc, 1989.

Komariah, Aan., \& Cepi Triatna. Visionary Leadership. Jakarta : Bumi Aksara, 2006.

Lazaruth, Soewaji. Kepala Madrasah Dan Tanggung Jawabnya. Yogyakarta : Penerbit Kanisius, 1993. 
Mudafir, Ilyas. Manajemen Mutu Terpadu. Buletin Pengawasan No. 13 dan 14 Tahun 1998.

Mulyadi. Total Quality Manajemen. Yogyakarta: UGM, 1998.

Mulyasa, E. Pedoman Manajemen Berbasis Madrasah. Jakarta : Departemen Agama RI, Direktorat Jenderal Kelembagaan Agama Islam, 2005.

Munizu, Musran. "Praktik Total Quality Management (TQM) Dan Pengaruhnya Terhadap Kinerja Karyawan (Studi Pada PT. Telkom Tbk. Cabang Makassar)" Jurnal Manajemen dan Kewirausahaan Fakultas Ekonomi Universitas Kriten Petra Surabaya, Vol.12, No. 2, September 2010.

Muttaqin, Galih Fajar., \& Dharmayanti, Rita. "Pengaruh Implementasi Total Quality Management terhadap Kinerja Keuangan Dengan Kualitas Kinerja Sebagai Variabel Intervening" Jurnal Akuntansi Fakultas Ekonomi Universitas Tarumanegara, Vol. XIX, No. 01, Januari 2015.

Nasution. Manajemen Mutu Terpadu (Total Quality Management). Jakarta : Ghalia Indonesia, 2001.

Nurhayati, Djamas. Madrasah Mandiri. Jakarta :Puslitbang Pendidikan Agama dan Keagamaan, 2005.

Partanto, Pius A., M. Dahlan Al-Barry. Kamus Ilmiah Populer. Surabaya: Apollo, 1994.

Sallis, Edward. Total Quality Management in Education. Jogjakarta : IRCiSoD, 2007. Siagian, Sondang P. Organisasi, Kepemimpinan dan Perilaku Administrasi. Jakarta: Gunung Agung, 1982.

Soetopo, Hendyat., \& Wasty Soemanto. Pembinaan dan Pengembangan Kurikulum Sebagai Subtansi Problem Administrasi Pendidikan. Jakarta : Bumi Aksara, 1993.

Sudarwan, Danim. Inovasi Pendidikan: Dalam Upaya Meningkatkan Profesionalisme Tenaga Kependidikan. Bandung : Pustaka Setia, 2002.

Sudrajat, Akhmad. Kompetensi Guru dan Peran Kepala Madrasah dalam http://www.depdiknas.go.id/ inlink.

Syafruddin. Manajemen Lembaga Pendidikan Islam. Jakarta : Ciputat Press, 2005. The New Oxford Illustrated Dictionary. London: Oxford University Press, 1982.

Timpe. A. Dale. The Art and Science of Business Management Leadership. New York : Kend Publishing, Inv, 1987.

Tjiptono, Fandy., \& Anstasia Dian. Total Quality Manajemen. Yogyakarta: Andi, 2001.

Wahjosumijo. Kepemimpinan Kepala Madrasah. Jakarta : Raja Grafindo Persada, 1999. 